\title{
The Anatomical Structure of Leaves and Thorns Plants Astragalus pterocephalus Bunge, Growing in Uzbekistan
}

\author{
Manzura A. Agzamova1, Guljan M. Duschanova², Hasan A. Rakhmatov', Abdulaziz A. Janibekov1 \\ ${ }^{1}$ Institute of Plant Chemistry Named after Acad. S. Yu. Yunusov Academy of Sciences of the Republic of Uzbekistan, Tashkent, \\ Uzbekistan \\ ${ }^{2}$ Laboratory Anatomy and Cytoembryology of the Tashkent Botanical Garden Named after Academician F.N. Rusanov, Institute \\ of Botany of the Academy of Sciences, Tashkent, Uzbekistan \\ Email: guljon.duschanova@mail.ru
}

How to cite this paper: Agzamova, M.A., Duschanova, G.M., Rakhmatov, H.A. and Janibekov, A.A. (2020) The Anatomical Structure of Leaves and Thorns Plants Astragalus pterocephalus Bunge, Growing in Uzbekistan. American Journal of Plant Sciences, 11, 569-577.

https://doi.org/10.4236/ajps.2020.114042

Received: September 23, 2019

Accepted: April 23, 2020

Published: April 26, 2020

Copyright ( 2020 by author(s) and Scientific Research Publishing Inc. This work is licensed under the Creative Commons Attribution International License (CC BY 4.0).

http://creativecommons.org/licenses/by/4.0/

\begin{abstract}
The results of a study conducted by light microscopy of the anatomical structure of the leaf and thorns of Astragalus pterocephalus growing in the natural habitat of the Amankutan Mountains of the Samarkand region (Uzbekistan) are presented. The following diagnostic features were identified: leaf-isolateral-palisade type of mesophyll leaf; thick-walled outer walls of the epidermis; the outline of epidermal cells is rectilinear, the projection is polygonal; amphystomatic leaves; submerged numerous stomata of hemiparacitic and anomocytic type; chlorophyll-bearing palisade and spongy parenchyma; closed collateral type of vascular bundles and more sclerified, due to sclerenchymal cells. Thorn-parenchymal-beam type of structure; thin-walled outer walls of the epidermis; under the epidermis is a lamellar collenchyma; closed collateral type of vascular bundles and more sclerified, due to sclerenchymal cells. The complex of the above features reflects the species specificity of the structure of the leaf and spines. Identified and described features that can be used in the taxonomy of the studied tribes and can serve to identify plant materials.
\end{abstract}

\section{Keywords}

Astragalus pterocephalus, Anatomy, Leaf, Thorn, Amankutan Mountains Samarkand

\section{Introduction}

A number of representatives of plants of the genus Astragalus are used in traditional medicine of many peoples of the world. This genus is represented in the 
flora of Central Asia by 592 species, in Uzbekistan-239 [1]. According to the literature the genus Astragalus L. is very extensive and polymorphic, numbering from 1200 to 2200 species [2]-[7], the world's flora.

In the early 80-ies in chemistry lab glycosides, Institute of Plant Chemistry of the Academy of Sciences of the Republic of Uzbekistan for the first time shown that plants of the genus Astragalus (Leguminosae) produces triterpene glycosides cycloartane series. Subsequently, our scientists and foreign colleagues discovered glycosides of this class with a wide spectrum of biological activity: cardiotonic, hypotensive, hypoglycemic, hypocholesterolemic and anti-blastoma.

Preparations based on biologically active substances from Astragalus sieversianus Pall. have hypocholesterolemic activity [8] [9], contributing to the normalization of lipid metabolism and improving cardiac activity. The activity of glycosides-Cyclosiversioside A and Cycloorbicoside G on metabolic processes in rat myocardium was revealed [10] [11]. Cycloartane glycosides isolated from Astragalus orbiculatus showed an interferon inducing effect [12], cytotoxic activity [13].

A wide pharmacological and chemical study of glycoside, Cyclosiversioside F-3-O- $\beta$-D-xylopyranoside, 6-O- $\beta$-D-glucopyranoside-20R, $24 \mathrm{~S}$-epoxycycloartan-3 $\beta, 6 \alpha, 16 \beta, 25$-tetraol, is currently underway which was obtained from a wild plant Astragalus pterocephalus, an astragalus of the winged-headed legume family, Leguminosae [14] [15].

The main goal of this scientific study is to study the anatomical structure and determine the diagnostic characteristics of the leaves and thorns of the medicinal plant Astragalus pterocephalus, the main component of which is the triterpene glycoside of the cycloartan series Cyclosiversiverside F.

\section{Materials and Methods}

Astragalus pterocephalus Bunge (Tragacantha pterocephala Bunge.)-perennial branched shrub up to $1.5 \mathrm{~m}$ in height; the branches are covered with straight, 5 $7 \mathrm{~cm}$ long, thick, slightly deviated, often blackening, spines (altered leaf petioles). Stipules about $1.5 \mathrm{~cm}$ long, lanceolate, sharp, membranous, almost transparent, multi-nerve, silky-hairy on the outside at the bottom. Leaflets are 4 -5-paired, oblong-lanceolate, 15 - $17 \mathrm{~mm}$ long, about 3 - 4-(5) $\mathrm{mm}$ wide, green, sparsely pressed on both sides of the hairy. Flowers in the axils of the leaves of $10-12$, collected in spherical inflorescences $3-5 \mathrm{~cm}$ wide. Bracts oblong-lanceolate, about $15 \mathrm{~mm}$ long, transparent, yellowish, one-nervous, glabrous, ciliate along the edge. Calyx 18 - $25 \mathrm{~mm}$ long, long and densely hairy, its teeth thin, purple, almost twice as long as the tube, covered with long protruding hairs. Flag about 17 $\mathrm{mm}$ long, shorter than calyx; its plate is narrowed upward, almost without ears, longer than a wide marigold. The wings are shorter than the flag; plate $1-1.5$ $\mathrm{mm}$ wide, almost twice as short as a marigold. The boat is slightly shorter than or equal to the wings. The column is only fluffy at the base. Bob is oblong-elliptical, white-haired. The seeds are kidney-shaped, about $3 \mathrm{~mm}$ long, 
light brown. The plant flowering in May-June bears fruit in July-August [1]. Species identified by F. O. Khassanov (Figure 1).

Plant samples were collected in the natural habitat of the Amankutan Mountains of the Samarkand region at the end of May and the beginning of June in the phase flowering 2018-2019 (Figure 2).

Astragalus pterocephalus grows on gravel, rocky and fine-grained slopes, on shale's, at heights of $1500-2000 \mathrm{~m}$. to the mountains of Amankutan, Samarkand region.

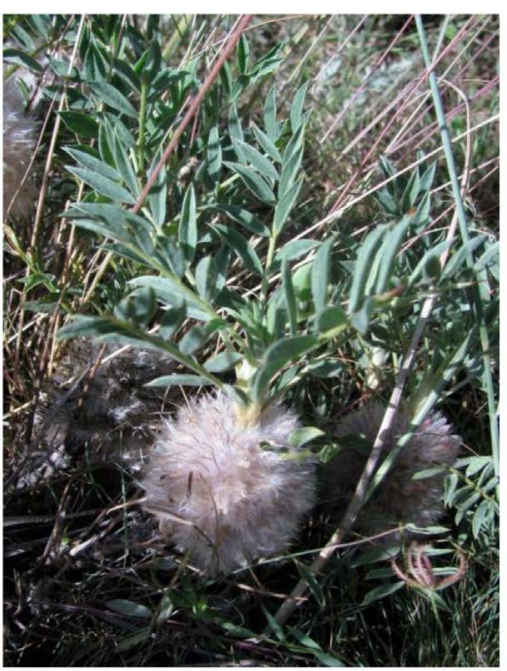

(a)

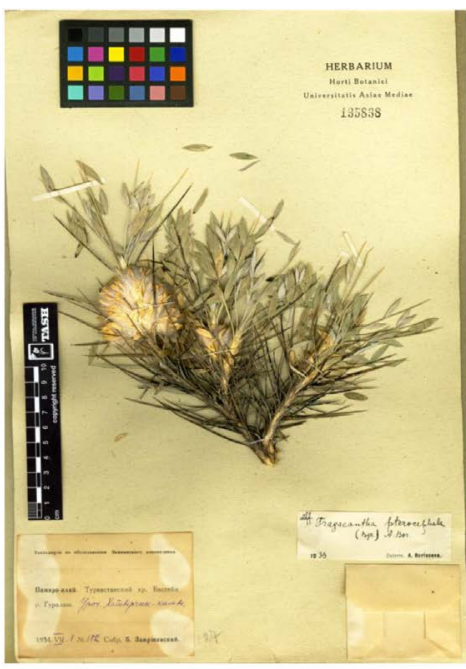

(b)

Figure 1. General view of Astragalus pterocephalus. (a) Nature; (b) Herbarium material of the Institute of botany of the academy of sciences of the republic of Uzbekistan.

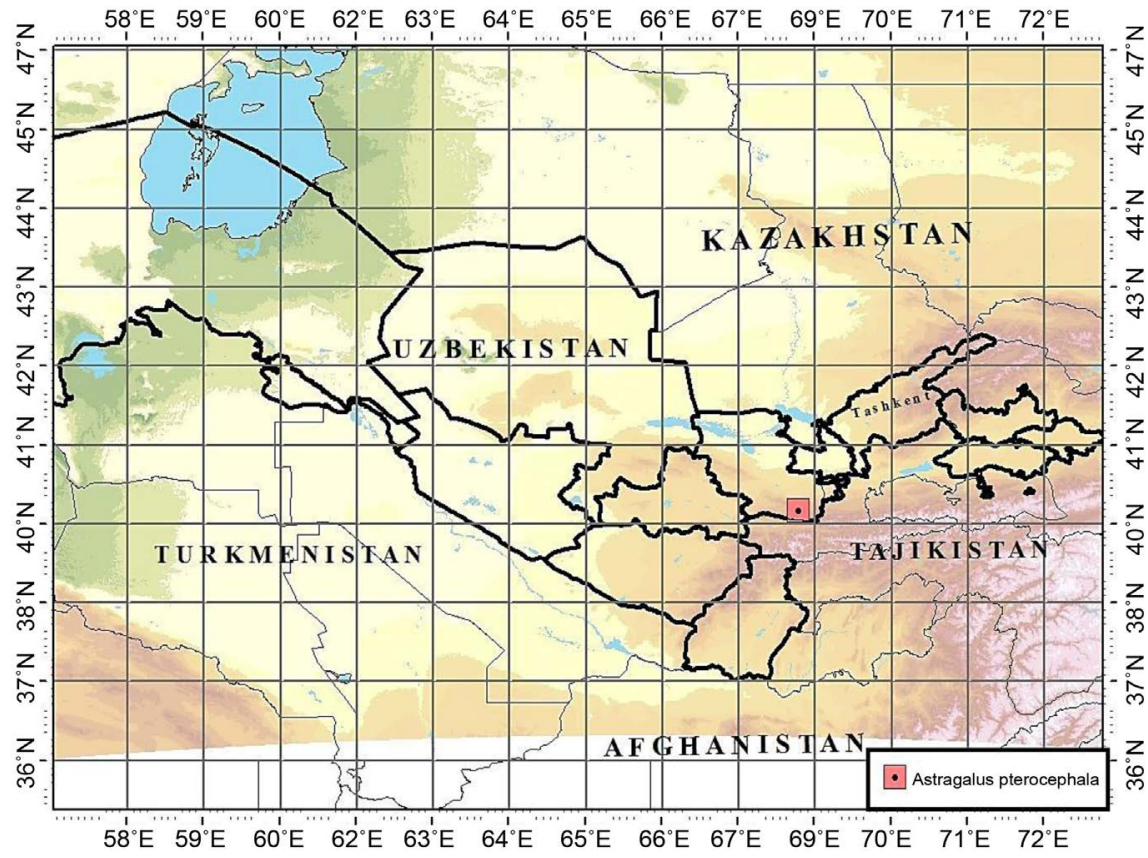

Figure 2. Map of the distribution of Astragalus pterocephalus in the flora of Uzbekistan. 
Amankutan is a mountain tract in the Zerafshan ridge with absolute elevations of $1000-2000 \mathrm{~m}$. the highest point of $2015 \mathrm{~m}$, low $1000 \mathrm{~m}$ above the sea. The difference in height is $1000 \mathrm{~m}$, which is typical of a typical mid-mountain relief.

The climate of Amankutan is sharply continental. The amplitudes of temperature fluctuations day and night, winter and summer are more pronounced than in the Zerafshan valley. Humidity here also changes more sharply than in the irrigated zone. Summer in Amankutan is cool, almost without precipitation with low relative humidity. At the end of May, all signs of summer, which lasts until mid-September, are already showing. The average July temperature is $24.5^{\circ} \mathrm{C}$, the maximum for the summer is $+35^{\circ} \mathrm{C}$. During this period, no more than 200 $\mathrm{mm}$ of atmospheric precipitation falls. The hottest month-July.

For the purpose of anatomical study and morphological description of the leaf and thorn, the plant was fixed in $70^{\circ}$ ethanol. The epidermis was studied on paradermal and transverse sections, transverse sections of the leaf were made through the middle, thorns from the base. Descriptions of the main tissues and cells are given according to C. Esau [16], N. S. Kiseleva [17] and the epidermis according to S. F. Zakharevich [18]. Manual preparations were stained with methylene blue, followed by gluing in glycerol-gelatin [19]. Microphotographs were taken using a computer microphotograph of a Canon A123 digital camera under a Motic B1-220A-3 microscope.

\section{Results and Discussion}

The leaf is a vegetative organ of the plant, performing the function of photosynthesis, transpiration and gas exchange.

On the paradermal section, the outlines of the epidermal cells of the leaf are rectilinear, the projection is polygonal. However, the upper epidermis is somewhat different from the lower epidermis. The cells of the upper epidermis are larger than the lower. The leaves are amphystomatic, stomata are located on both sides of the leaf blade, located transversely to the longitudinal axis of the leaf. The shape of the stomata is round. The upper (adaxial) epidermis has a significantly smaller number of stomata compared to the lower (abaxial) epidermis. All this leads to a reduction in water loss from the surface of the sheet. The closing stomata cells on both sides of the leaf are almost the same length. Stomata submerged, hemiparacytic and anomocytic types (Figure 3 and Figure 4).

The mesophyll of the leaf on the cross-section of the isolate-palisade type, is represented by 2 rows of palisade cells on both sides of the leaf and a spongy layer of different thickness between them. The epidermis is represented by one row of cells with a thick-walled cuticle layer. Adaxial epidermal cells are larger than abaxial.

An assimilation tissue consisting of palisade and spongy cells is located between the adaxial and abaxial epidermis. The palisade parenchyma is chlorophyll-bearing, large and elongated, which consists of 2 rows of cells and is located 


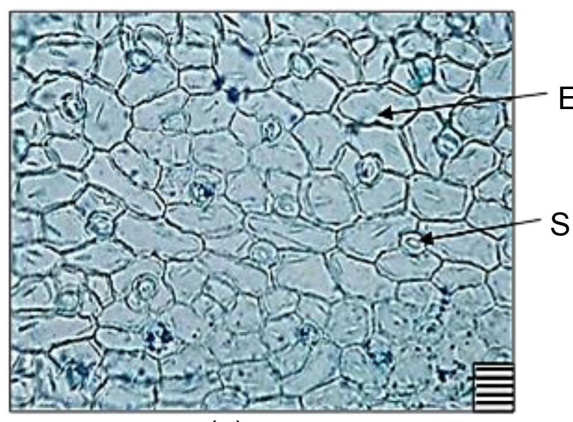

(a) $50 \mu \mathrm{m}$
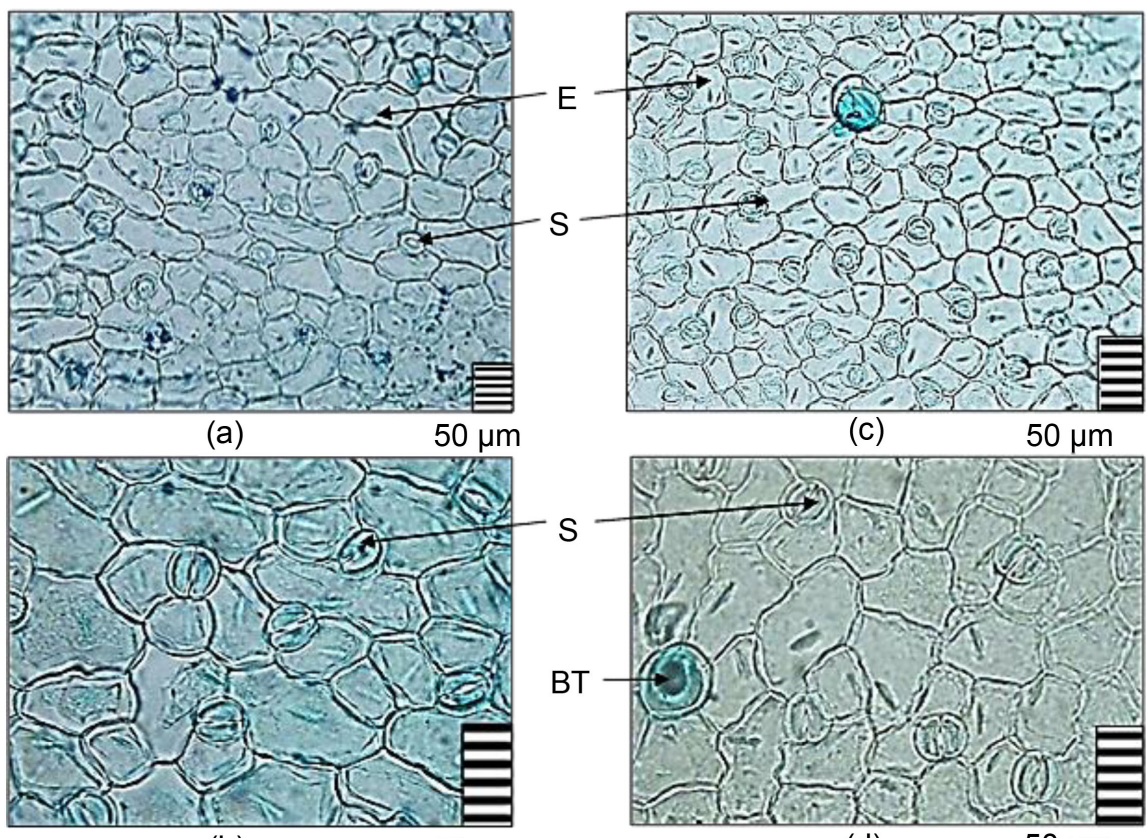

(b)

$50 \mu \mathrm{m}$

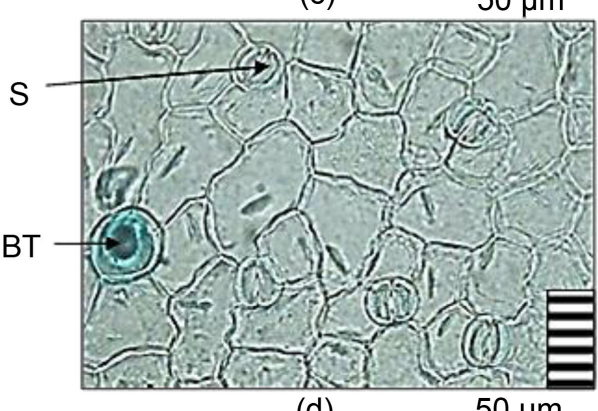

(d)

$50 \mu \mathrm{m}$

Figure 3. The structure of the epidermis of leaf of the Astragalus pterocephalus on a paradermal section: (a)-(b) adaxial epidermis; (c)-(d) abaxial epidermis. Legend: BT-base of the trachoma, E-epidermis, S-stomata. Magnification-50 micron.

between the adaxial and abaxial leaf epidermis.

The spongy chlorophyll-bearing parenchyma consists of 3 - 4 rows and is located between the palisade parenchyma. The spongy parenchyma is round, small-cell with small cavities. Between palisade and spongy cells, the main and lateral vascular bundles are located.

The main and lateral conducting bundles protrude on the abaxial side and are located in the central part of the leaf mesophyll. Vascular bundles are most sclerified, due to the presence of mechanical tissues (sclerenchyma) in them (Figure 4).

Under the abaxial epidermis and above the main vascular bundles, there is a 2-row lamellar collenchyma. Large and small conductive beams alternate with each other. Vascular bundles of closed collateral type, numerous, consisting of phloem and xylem (Figure 4).

Thorn. On the cross-section, oval or heart-shaped, parenchymal-beam type of structure. The epidermis is single-row, oval and thin-walled. Collenchyma lamellar, thickened consists of $3-4$ rows. Under the collenchyma is a rounded oval cortex parenchyma, which consists of 5 - 6 rows (Figure 5).

Vascular bundles of a circular arrangement, the phloem is extensive, the xylem is round-oval, large and small. Vascular bundles are most sclerified, due to the presence of mechanical tissues (sclerenchyma) in them.

Large and small conductive beams alternate with each other. Vascular bundles of closed collateral type, numerous, consisting of a phloem and xylem. The core is extensive, parenchymal cells are round, thick-walled, among which there are 


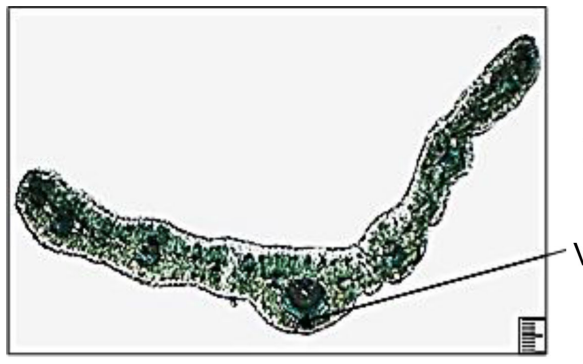

(a)

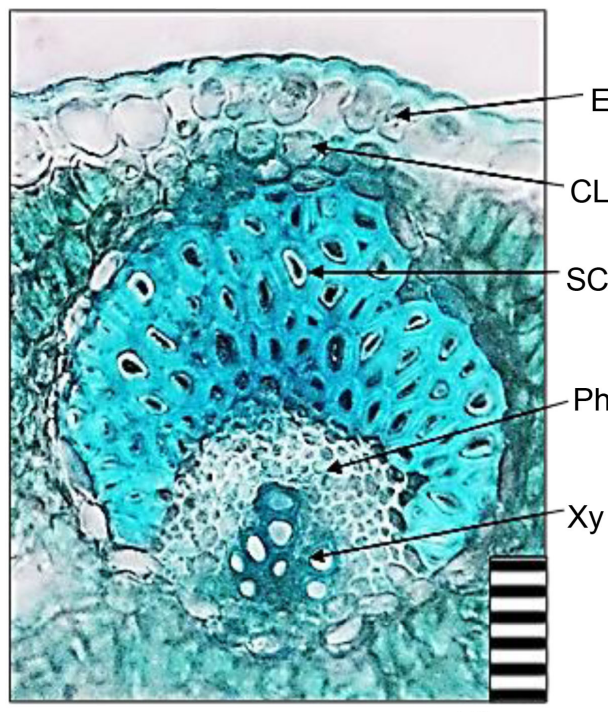

(c)

$50 \mu \mathrm{m}$

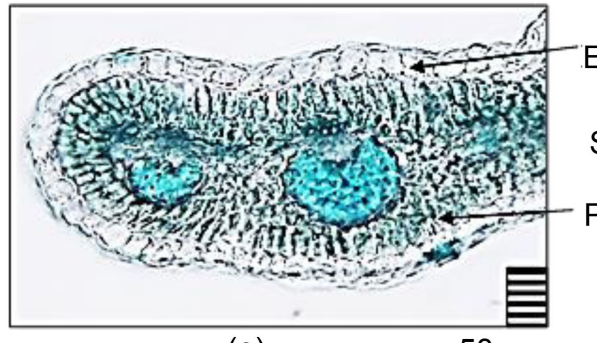

(e)

$50 \mu \mathrm{m}$

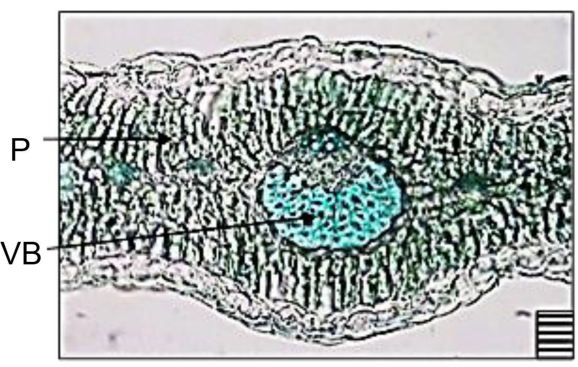

(b)

$50 \mu \mathrm{m}$

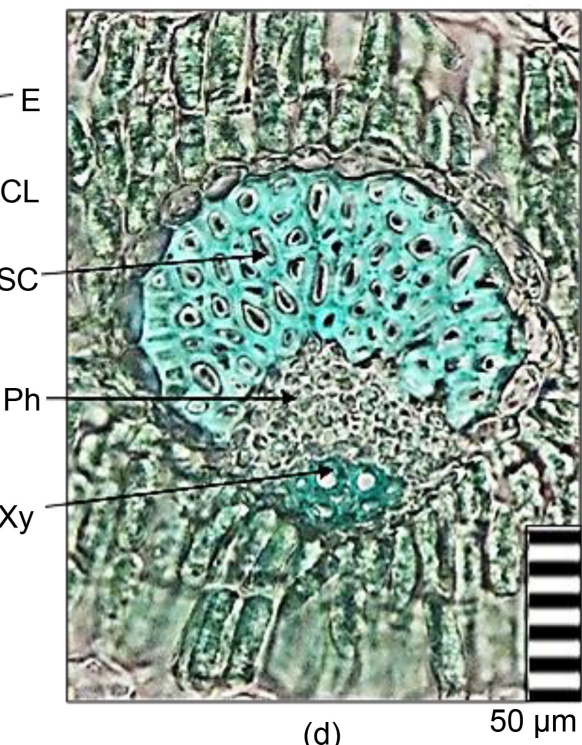

(d)

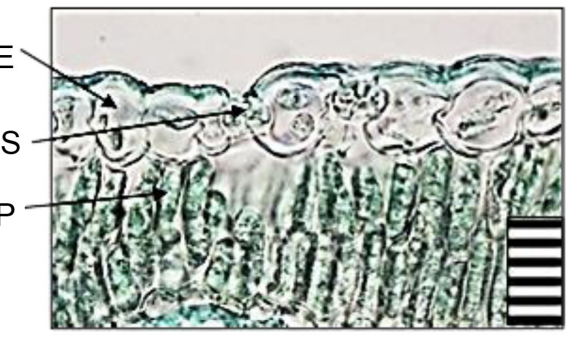

(f)

$50 \mu \mathrm{m}$

Figure 4. Anatomical structure of the mesophyll of leaf of the Astragalus pterocephalus on a cross section: (a) General view of the leaf mesophyll; (b) Detail; (c)-(d) Conductive bundles; (e) The edges of the leaf; (f) Submerged stomata. Legend: CL-collenchyma, E-epidermis, $\mathrm{P}$-palisade parenchyma, $\mathrm{Ph}$-phloem, S-stomata, SC-sclerenchyma, VB-vascular bundles, Xy-xylem. Magnification-50 - 100 micron.

hydrocytic cells (Figure 5).

Thus, the anatomical structure of the leaf and spines of Astragalus pterocephalus was studied and the following diagnostic signs were determined: leaf-isolateral-palisade type of mesophyll leaf; thick-walled outer walls of the epidermis; the outline of epidermal cells is rectilinear, the projection is polygonal; amphystomatic leaves; submerged numerous stomata of hemiparacitic and anomocytic type; chlorophyll-bearing palisade and spongy parenchyma; closed collateral type of vascular bundles and more sclerified, due to sclerenchymal cells. Thorn-parenchymal-beam type of structure; thin-walled outer walls of the 


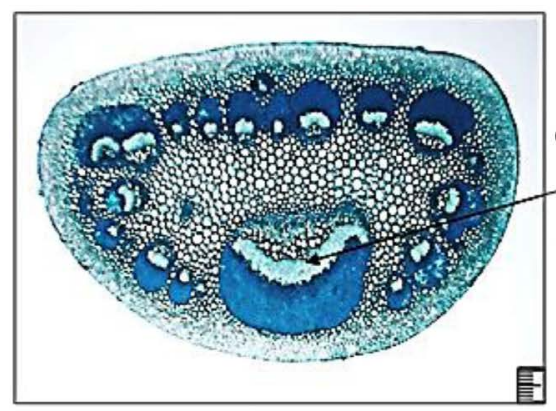

(a) $100 \mu \mathrm{m}$

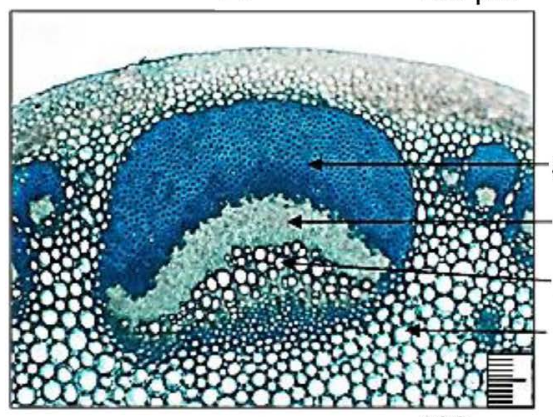

(c)

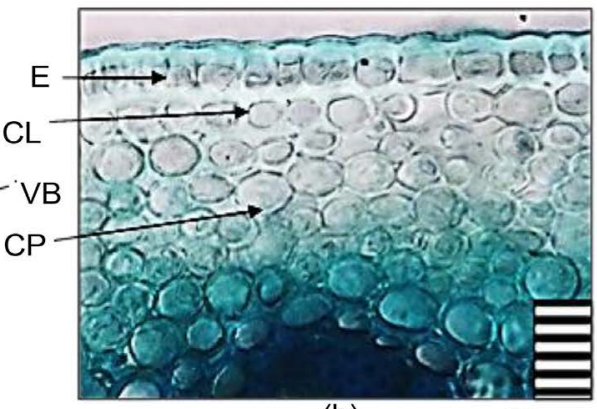

(b)

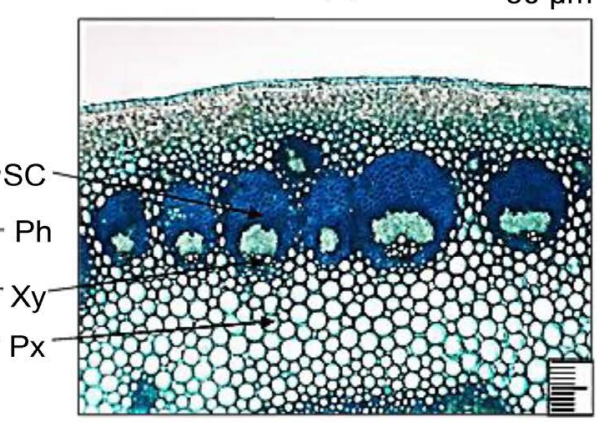

(d) $100 \mu \mathrm{m}$

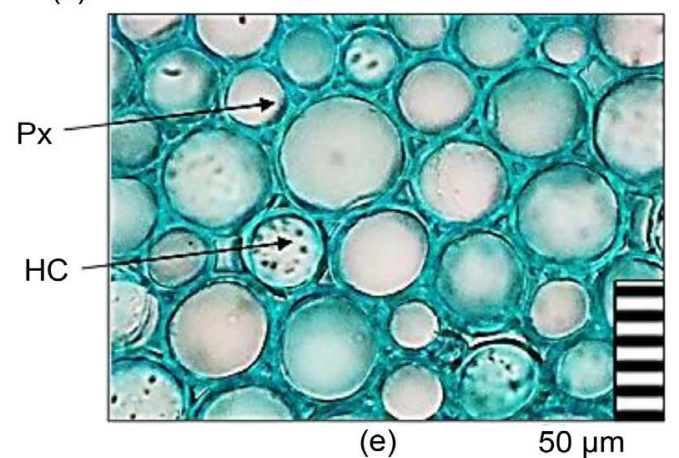

Figure 5. Anatomical structure of the thorn of Astragalus pterocephalus in a cross section: (a) General view of the spine; (b) Detail; (c)-(d) Vascular bundles; (e) Parenchymal and hydrocytic cells. Legend: $\mathrm{CL}$-collenchyma, $\mathrm{CP}$-cortex parenchyma, E-epidermis, HC-hydrocytic cells, $\mathrm{Ph}$-phloem, Px-parenchyma, SC-sclerenchyma, VB-vascular bundles, Xy-xylem. Magnification-50 - 100 micron.

epidermis; under the epidermis is a lamellar collenchyma; closed collateral type of vascular bundles and more sclerified, due to sclerenchymal cells. The diagnostic characters that we have identified reflect more xeromorphicity of this species and can be used in the taxonomy of the studied tribes, and can also serve to identify plant materials.

\section{Acknowledgements}

The work was carried out with financial support from the State Foundation for Basic Research of the Republic of Uzbekistan (under grant No. VA-FA-F7-009).

\section{Conflicts of Interest}

The authors declare no conflicts of interest regarding the publication of this paper. 


\section{References}

[1] Borisova, A.G. (1955) Genus Tragacantha. Flora of Uzbekistan, 3, 684-685. (In Russian)

[2] Vasilieva, L.I. (1987) Genus Astragalus L.-Astragalus. Flora of the European Part of the USSR, 6, 47-76. (In Russian)

[3] Vydrina, S.N. (1994) Genus Astragalus L.-Astragalus. Flora of Siberia, 9, 20-74.(In Russian)

[4] Kamelin, R.V. (1986) Genus Astragalus L.-Astragalus. Areas of Trees and Shrubs of the USSR, 3, 26-50.(In Russian)

[5] Kobeleva, T.P. (1976) Genus Astragalus L.-Astragalus. Flora of the Northeast of the European Part of the USSR, 3, 165-168.(In Russian)

[6] Kulikov, P.V. (2000) A New Species of the Genus Astragalus L. (Fabaceae) from the Southern Urals. News of the Systematics of Higher Plants, 32, 90-91. (In Russian)

[7] Skachko, A.A. (2001) Genus Astragalus L. (Fabaceae) in the Flora of the Altai Territory and the Republic of Altai. Flora and Vegetation of Altai, 6, 50-69. (In Russian)

[8] Gan, N., Chen, Y. and Han, K. (1986) Triterpenoid Glycosides from A. sieversianus Pall. Abstract Journal of Chemistry, 1, 37-40.

[9] Bazhenova, E.D., Aliev, H.U. and Sultanov, M.B. (1979) On the Pharmacology of New Saponins Isolated from Plants of Central Asia. Pharmacology of Natural Compounds, 89-94. (In Russian)

[10] Khushbaktova, Z.A., Agzamova, M.A., Syrov, V.N., Mirsalikhova, N.M., Umarova, F.T. and Isaev, M.I. (1994) The Effect of Cycloartans of Plants of the Genus Astragalus and Their Synthetic Analogues on the Contractile Function of the Myocardium and the Activity of Na, K-ATPase. Chemistry of Nature. Connection 4, 510-514. (In Russian) https://doi.org/10.1007/BF00630402

[11] Tsaruk, A.V., Iskenderov, D.A., Agzamova, M.A., Khushbaktova, Z.A., Syrov, V.N. and Isaev, M.I. (2010) Isolation and Study of the Effects of Cycloartan Glycosides of Cycloorbicoside G and Cyclosiversioside A on Metabolic Processes in the Rat Myocardium. Chemical Pharmaceutical Journal, 44, 12-15. (In Russian) https://doi.org/10.1007/s11094-010-0388-7

[12] Japanese Patent 1984, 59, 36, 623. Interferon Inductor. RJ Chem., 1985.50233 p. (In Russian)

[13] Agzamova, M.A. and Isaev, I.M. (2016) Plant Components Astragalus pterocephalus. Chemistry of Natural Compounds, 52, 501-502. https://doi.org/10.1007/s10600-016-1687-3

[14] Agzamova, M.A. and Isaev, I.M. (2017) Cytotoxic Activity of the Cycloorbicoside A and Its Derivatives. Advance Pharmaceutical Journal, 2, 46-48.

[15] Tsaruk, A.V., Isaev, I.M., Agzamova, M.A., Vypova, N.L., Khushbaktova, Z.A., Syrov, V.N. and Isaev, M.I. (2010) A Study of the Effects of Cyclosiversiverside F on the Blood Coagulation System. Uzbek Biological Journal, 5, 10-13. (In Russian) https://doi.org/10.1007/s11094-010-0388-7

[16] Esau, K. (1969) Anatomy of Plants. Publishing House World, Moscow, 138-416. (In Russian)

[17] Kiseleva, N.S. (1971) Anatomy and Morphology of Plants. Publ. High School, Minsk, 89-119, 2015-227. (In Russian)

[18] Zakharevich, S.F. (1954) To the Methodology for Describing the Epidermis of the 
Leaf. Bulletin of Leningrad State University, 4, 65-75.(In Russian)

[19] Barykina, R.P. and Chubatova, N.V. (2005) A Large Workshop on the Ecological Anatomy of Flowering Plants. Association of Scientific Publications, Moscow, 77. (In Russian) 